\title{
Pericytic Neoplasm
}

National Cancer Institute

\section{Source}

National Cancer Institute. Pericytic Neoplasm. NCI Thesaurus. Code C6528.

A benign or malignant mesenchymal neoplasm arising from the perivascular cells of the connective and soft tissues. It is characterized by the presence of pericytes that grow in a circumferential pattern around vessels. 